Back to results $\mid 1$ of 3 Next >

Full Text $\mid$ View at Publisher |

Asia-Pacific Journal of Clinical Oncology

Volume 11, Issue 3, 1 September 2015, Pages 221-227

\title{
Survival of lung cancer patients in a resource-limited country (Aricle)
}

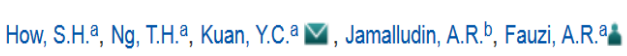

a Department of Internal Medicine, Kulliyyah of Medicine, Intemational Islamic University Malaysia Kuantan. Pahang, Malaysia

${ }^{b}$ Department of Public Health, Kulliyyah of Medicine, International Islamic University Malaysia, Kuantan, Pahang, Malaysia

Abstract

$\checkmark$ View references $(20)$

Aim: Data on lung cancer survival are lacking in developing countries. Our objectives were to describe the survival of our lung cancer patients and to determine independent prognostic factors affecting survival. Method: All patients diagnosed with lung cancer from August 2007 to August 2010 were recruited from a single referral hospital of the state of Pahang, Malaysia. Detailed demographic data, ECOG (Eastern Cooperation Oncology Group) performance status, stage of disease and treatment were recorded. The date of histology or cytology confirmation was used as the date of entry. Survival time was calculated from the date of entry to the date of death. Results: One hundred forty-nine patients were included for survival analysis. The median age was 62 years and patients were predominantly males $(78 \%)$ and smokers $(78 \%)$. The majority had non-small cell lung cancer (NSCLC) $(94 \%)$; only six patients $(4 \%)$ had small cell lung cancer. All patients presented with stage 3 or stage 4 disease. Overall median survival was 18 weeks. "No definitive treatment" and "ECOG 3-4" were the significant independent predictors of death, with the hazard ratios of 2.1 (95\% confidence interval $[\mathrm{Cl}] 1.4,3.0)$ and $1.6(95 \% \mathrm{Cl} 1.1,2.3)$ times, respectively. Among NSCLC patients on treatment, 1- and 2-year survival rates were $27 \%$ and $15 \%$, respectively. Conclusion: The majority of lung cancer patients in Pahang presented with advanced disease. No definitive treatment and ECOG 3-4 were independent poor prognostic factors. (C) 2015 Wiley Publishing Asia Pty Lto.

\section{Author keywords}

Factors; Lung cancer; Median survival; Outcome

Indexed keywords

EMTREE medical terms: adult; age distribution; aged; Article; cancer patient; cancer prognosis; cancer staging; cancer survival; Chinese; ethnicity; female; human; lung cancer; major clinical study; Malay; Malaysia; male; non small cell lung cancer; overall survival; priority journal; small cell lung cancer; survival rate; survival time

ISSN: 17437555 Source Type: Journal Original language: English

DOl: $101111 /$ ajco. 12179 Document Type: Article

Publisher: Blackwell Publishing Lto

\section{Cited by 0 documents}

Inform me when this document is cited in Scopus:

Set cilation alert | Set citation feed

\section{Related documents}

Survival of small-cell lung cancer and its determinants of outcome in Singapore Toh, C.K., Hee, S.W. Lim, W.-T.

(2007) Annals of the Academy of Medicine Singapore

The role of mutation status of the epidermal growth factor receptor gene in advanced non-small cell lung cancer

Vaguliene, N. Žěmailis, M. , šarauskas, V.

(2012) Medicina (Lithuania)

Ovarian cancer survival population differences: A "high resolution study" comparing Philippine residents, and Filipino-Americans and Caucasians living in the US

, A. , Mirasol-Lumague, M.R. (2009) BMC Cancer

View all related documents based on references

Find more related documents in Scopus based on

(9) Authors Keywords 